\title{
The real impact of affective temperaments: new perspectives from Argentina Gustavo Hictor Vázquez
}

\author{
Address: Department of Neuroscience, University of Palermo, Buenos Aires, Argentina \\ from International Society on Brain and Behaviour: 3rd International Congress on Brain and Behaviour \\ Thessaloniki, Greece. 28 November - 2 December 2007 \\ Published: 17 April 2008 \\ Annals of General Psychiatry 2008, 7(Suppl I):S6I doi:I0.II86/I744-859X-7-SI-S6 I
}

This abstract is available from: http://www.annals-general-psychiatry.com/content/7/SI/S6I

(C) 2008 Vázquez; licensee BioMed Central Ltd.

\section{Background}

We have examined the prevalence of affective temperaments between clinically unaffected relatives of bipolar patients and investigated the impact of these "subaffective" forms on their quality of life (QoL) in seven sites across Argentina.

\section{Material and methods}

We administered the scales TEMPS-A Buenos Aires [1] and Quality of Life Index-Spanish version, to a sample of nonill first degree relatives of bipolar disorder patients ("cases") and controls without family history of affective illness.

\section{Results}

Mean scores on all TEMPS-A subscales were significantly higher in cases, except for hyperthymia. The prevalence of affective temperaments, according to Argentinean cut-off points [2], was also higher, with statistical signification for cyclothymic and anxious temperaments. Regarding QoL, we have found an affectation of QoL domains for all temperaments, except hyperthymia. Both findings support the concept of a spectrum of subthreshold affective traits or temperaments in bipolar pedigrees [3].

\section{Discussion}

Our study confirms that healthy relatives of bipolar probands exhibit a higher degree of temperamental dysregulation than normal controls and demonstrates that affective temperaments can serve as an endophenotype for bipolar disorder [4] as judged by the fact that "clinically well" relatives show these traits at a statistically significantly higher than appropiately chosen controls.

In this study we go beyond these considerations to test the hyphotesis that the "well relatives" of bipolar probands not only exhibit such traits, but could also show some impairment as a result of a temperamental foundation. Our results support the idea that predominant temperaments have a direct impact on their quality of life (QoL).

\section{References}

I. Vázquez GH, Akiskal HS: The temperament evaluation of the Memphis, Pisa, Paris, and San Diego autoquestionnaire, Argentine version (TEMPS-A Buenos Aires). Vertex, Rev Arg Psiquiatria 2005, 16:89-94.

2. Vázquez GH, Nasetta S, Mercado B, Romero E, Tifner S, Ramón Mdel L, Garelli V, Bonifacio A, Akiskal KK, Akiskal HS: Validation of the TEMPS-A Buenos Aires: Spanish psychometric validation of affective temperaments in a population study of Argentina. J Affect Disord 2007, 100:23-29.

3. Akiskal HS, Pinto O: The evolving bipolar spectrum: protoypes I, II, III, IV. Psychiatr. Clin. North Am. 1999, 22:5 I7-534.

4. Gonda X, Rihmer Z, Zsombok T, et al.: 5HTTLPR polymorphism of the serotonin transporter gene is associated with affective temperaments as measured by TEMPS-A. J Affect Disord 2006, 91:125-3I. 